\title{
Bisphenol A and phthalate endocrine disruption of parental and social behaviors
}

\author{
Cheryl S. Rosenfeld* \\ Bond Life Sciences Center, Genetics Area Program, Biomedical Sciences, University of Missouri, Columbia, MO, USA
}

\section{Edited by:}

Hubert Vaudry, University of Rouen,

France

\section{Reviewed by:}

John Vandenbergh, Duke University, USA

Marie-chantal Canivenc-lavier,

French National Institute for

Agricultural Research, France

*Correspondence:

Cheryl S. Rosenfeld, Bond Life

Sciences Center, Genetics Area

Program, Biomedical Sciences,

University of Missouri, 1201 E.

Rollins Rd., Columbia, MO

65211, USA

e-mail: rosenfeldc@missouri.edu
Perinatal exposure to endocrine disrupting chemicals (EDCs) can induce promiscuous neurobehavioral disturbances. Bisphenol $A$ and phthalates are two widely prevalent and persistent EDCs reported to lead to such effects. Parental and social behaviors are especially vulnerable to endocrine disruption, as these traits are programmed by the organizational-activational effects of testosterone and estrogen. Exposure to BPA and other EDCs disrupts normal maternal care provided by rodents and non-human primates, such as nursing, time she spends hunched over and in the nest, and grooming her pups. Paternal care may also be affected by BPA. No long-term study has linked perinatal exposure to BPA or other EDC and later parental behavioral deficits in humans. The fact that the same brain regions and neural hormone substrates govern parental behaviors in animal models and humans suggests that this suite of behaviors may also be vulnerable in the latter. Social behaviors, such as communication, mate choice, pair bonding, social inquisitiveness and recognition, play behavior, social grooming, copulation, and aggression, are compromised in animal models exposed to BPA, phthalates, and other EDCs. Early contact to these chemicals is also correlated with maladaptive social behaviors in children. These behavioral disturbances may originate by altering the fetal or adult gonadal production of testosterone or estrogen, expression of ESR1, ESR2, and $A R$ in the brain regions governing these behaviors, neuropeptide/protein hormone (oxytocin, vasopressin, and prolactin) and their cognate neural receptors, and/or through epimutations. Robust evidence exists for all of these EDC-induced changes. Concern also exists for transgenerational persistence of such neurobehavioral disruptions. In sum, evidence for social and parental deficits induced by BPA, phthalates, and related chemicals is strongly mounting, and such effects may ultimately compromise the overall social fitness of populations to come.

Keywords: EDC, bisphenol A, phthalate, xenoestrogen, rodent models, brain development, epigenetics, neuropeptides

\section{INTRODUCTION}

The perinatal environment can dramatically shape later adult behaviors, and these disruptions can be propagated through transgenerational transmission to future generations (Rosenfeld, 2014). The impact of varying parental investment on offspring brain development is also gaining interest (Dulac et al., 2014; Rilling and Young, 2014). Disturbances in parental behaviors, such as nursing/feeding, huddling over, and grooming the neonates can have dramatic epigenetic and phenotypic consequences that persist for generations to come (Weaver et al., 2006).

Due to underlying neural disruptions, parental and social behaviors can be impacted by developmental exposure to endocrine disrupting chemicals (EDCs). Strong conservation exists in brain development and function across species spanning from rodents to humans (Rice and Barone, 2000; Howdeshell, 2002). In animal models and humans, neurobehavioral development is vulnerable to EDCs, because of the organizationalactivational of endogenous steroidogenic hormones.
One of the most preeminent discoveries in neuroendocrinology in the last century was that sex steroid hormones, testosterone and estrogen, guide perinatal brain development in a sex dependent manner (Phoenix et al., 1959; Arnold and Breedlove, 1985; Morris et al., 2004). This early brain programming is termed the "organizational effects" of these steroid hormones. However, full elaboration of many sex-dependent behaviors requires a later surge of testosterone in adult males ("activational effects"). The organizational-activational effects of testosterone in many brain regions are due to aromatization to estrogen (Watson and AdkinsRegan, 1989; Konkle and McCarthy, 2011). Exposure to EDCs that disrupt these normal steroidogenic effects may thus result in neurobehavioral deficits, including social and parental behavioral deficits.

The two most common EDCs associated with parental and social behavioral disturbances are bisphenol A (BPA) and phthalates. Therefore, these two will be the primary focus, although, where appropriate, effects of other EDCs on these traits will be discussed. BPA is one of the most widely prevalent EDCs 
with production currently reported to be in excess of 15 billion pounds per year (Vandenberg et al., 2013; Grandviewresearch, 2014). BPA is present in a wide variety of commonly used products and applications, including polycarbonate plastics, the lining of metal food cans, certain dental sealants, thermal receipt paper, and many other items that are currently not required to be labeled that they contain BPA. The abundance of BPA has ensured extensive and longstanding exposure of animals and humans, including pregnant women (Environment Canada, 2008; Vandenberg et al., 2013). There is strong evidence that BPA is a neuroendocrine disruptor (Leon-Olea et al., 2014).

Di(2-ethylhexyl) phthalate (DEHP) is another ubiquitous EDC present in plastic products personal care products, paints, pharmaceuticals, food products, and textiles (Latini et al., 2003). Similar to BPA, this chemical can leach out of plastic products when heated. Its primary metabolite, mono-ethylhexyl-phthalate (MEHP) can also result in neuroendocrine disruption (LeonOlea et al., 2014).

This review will first consider the evidence that BPA, phthalates, and other EDCs can alter parental care provided by the mother and the scant evidence to date by the father. Next, we will consider the impact of developmental exposure to these chemicals on social behaviors in animal models and linkages in humans. Finally, the potential mechanisms by which EDCs may affect these behavioral patterns will be explored.

\section{EVIDENCE OF ENDOCRINE DISRUPTION OF PARENTAL BEHAVIORS}

There have been no long-term studies examining for potential linkage of early exposure to these chemicals and later parental behavior deficits in humans. Therefore, this section will focus on the existing evidence from rodent and other animal models (Summarized in Table 1). A handful of rodent studies have reported that early exposure to EDCs can result in later effects on maternal care. General maternal behaviors assessed in these collective studies include the amount of time the female spends nursing, hunched over and in the nest, grooming, and latency to retrieve her pups.

CD-1 female mice exposed orally during the fetal and/or adult period to BPA $(10 \mu \mathrm{g} / \mathrm{kg}$ body weight (bw)/day for gestational days 14-18) spend less time nursing their pups and huddling over them while in the nest (Palanza et al., 2002). Acute exposure of adult female Sprague-Dawley rats exposed to BPA $(40 \mu \mathrm{g} / \mathrm{kg}$ bw, orally per day) from mating to weaning of their pups disrupts both active and passive maternal care, manifested by decreased time licking and grooming the pups, a trend to less ano-genital licking, and less time assuming an arched-back posture to allow the pups to suckle (Della Seta et al., 2005). Similarly, Wistar female rats treated with $5 \mu \mathrm{g} \mathrm{BPA} / \mathrm{kg}$ bw/day from the first day of gestation through lactation (postnatal day, PND 21) decreased the amount of time they nursed and attended to their pups (Boudalia et al., 2014). Another study tested the effects of gestational exposure (0-19 days) to three oral doses of BPA $(2,20$, and $200 \mu \mathrm{g} / \mathrm{kg}$ bw/day) on maternal care provided by BALB/c mice. In contrast to the prior studies, the highest dose of BPA tested increased the amount of time females spent licking and grooming and nursing their pups in an arched back position (Kundakovic et al., 2013).

These conflicting rodent model findings may be attributed to various factors. First, all four of these above studies used rats or mice of different strains, and there is evidence of strain-specificity and phenotypic differences in response to BPA and other estrogenic EDC (Spearow et al., 1999, 2001; Kendziorski et al., 2012). The administered dose and timing, duration of exposure (perinatal vs. adult), and corresponding generational differences ( $\mathrm{F}_{0}$ vs. $\mathrm{F}_{1}$ ) may also be potential factors. Finally, differences in animal husbandry (composition of the cages and water bottles, dietphytoestrogen or non-phytoestrogen free, and shavings-corn cob or aspen) might account for the disparate rodent results.

Infants may influence, through vocalizations, direct contact, and other forms of communication, the amount of parental care provided to them with males tending to initiate and receive more parental investment (Della Seta et al., 2005; Hao et al., 2011). Early EDC exposure though may alter an infant's ability to stimulate maternal care provided to them. For instance, the behavioral patterns of Cynomolgus monkeys (Macaca fascicularis) male infants prenatally (gestational day 20 through term) exposed to BPA ( $10 \mu \mathrm{g} / \mathrm{kg}$ bw/day via osmotic pump) were more reminiscent of females, and these mothers nursed their "feminized" sons less than those rearing control males (Nakagami et al., 2009).

While there are no studies to date on whether acute and developmental exposure to phthalates affects maternal care, other EDCs have been reported to disrupt these behavioral patterns. Long-Evans (LE) rat pups prenatally exposed through their biological dam to the environmental chemical 3, 4, 3', 4'tetrachlorobiphenyl (PCB 77, $2000 \mu \mathrm{g} / \mathrm{kg}$ bw/day on gestational days 6 through 18 via daily subcutaneous injections) resulted in their foster dams spending an increased frequency nursing them and allogrooming (Cummings et al., 2005). This cross-foster approach further revealed the complex interactions exist between maternal and fetal exposure to PCB 77 and amount of time foster dams spent in the nest and grooming the pups, along with decreased duration engaged in high-crouch nursing. Perinatal exposure (either 3 days after the dam was paired with a male or 3 days after parturition of a previous litter through weaning of pups) via daily maternal oral dosing to diethylstilbestrol (DES, $0.2 \mu \mathrm{g} / \mathrm{kg}$ bw/day) or methoxychlor (MXC, $2000 \mathrm{mg} / \mathrm{kg}$ bw/day) of monogamous female pine voles did not however affect their later maternal care behaviors (Engell et al., 2006).

The impact of EDCs on later paternal care provided is largely unknown, probably because few mammalian species exhibit biparental care (Clutton-Brock, 1989). Yet, disturbances in paternal care may have dramatic epigenetic and phenotypic consequences that persist for several generations (Bredy et al., 2007; Braun and Champagne, 2014; McGhee and Bell, 2014). Even so, there have been no published rodent studies to date on how early exposure to EDCs affects paternal care. However, in polygynous sand gobies (Pomatoschistus minutus), where the male is responsible for tending the eggs, endocrine disruption of paternal care behaviors has been reported (Saaristo et al., 2010). Polygynous sand goby males compete for females and then assume responsibility for nest building and attendance. However, adult males 
Table 1 | Animal model and human epidemiological studies linking bisphenol A (BPA) and phthalates exposure to parental and social behavioral changes.

\begin{tabular}{lllll}
\hline Publication(s) & $\begin{array}{l}\text { Animal model/human } \\
\text { cohort population }\end{array}$ & $\begin{array}{l}\mathrm{EDC}(\mathrm{s}) \text { tested or } \\
\text { correlation analysis } \\
\text { performed }\end{array}$ & $\begin{array}{l}\text { Dosing regimen/method to } \\
\text { measure BPA concentrations }\end{array}$ & Major findings
\end{tabular}

\section{PARENTAL BEHAVIORS}

Palanza et al., 2002

CD1 female mice
Prenatal exposure of $F_{1}$ offspring to $10 \mu \mathrm{g} \mathrm{BPA} / \mathrm{kg}$ body weight (bw)/day or oil by oral administration through the $F_{0}$ dam from days 14 to 18 of gestation. Some $F_{1}$ adults (2-2.5 months of age) were also treated with $10 \mu \mathrm{g} \mathrm{BPA} / \mathrm{kg}$ bw/day or oil and treatments spanned from days 14 to 18 of gestation. There were thus those $F_{1}$ offspring who only received prenatal or adult exposure to BPA and those that were exposed to this chemical during the prenatal and adult periods resulting in four different treatment groups.

$\begin{array}{ll}\begin{array}{l}\text { Della Seta et al., } \\ 2005\end{array} & \begin{array}{l}\text { Sprague-Dawley female BPA } \\ \text { rats }\end{array}\end{array}$

$$
\text { rats }
$$

- $F_{1}$ females exposed to BPA during the prenatal or adult period spent spend less time nursing and huddling over the pups but greater time engaged in nest building than controls and those that received BPA during both time periods.
Boudalia et al., 2014 Wistar female rats BPA
Kundakovic et al., 2013
BALB/c mice

BPA

Adult exposure of $F_{0}$ dams to one of the three oral doses of BPA $(2,20$, $200 \mu \mathrm{g} / \mathrm{kg}$ bw/day) from gestational days 0 to 19 .
- Adult $F_{0}$ females exposed to the highest dose of BPA spent more time licking, grooming, and nursing their pups in an arched back position.

- No effects were reported with the lower two doses.
Adult $F_{0}$ exposure to $40 \mu \mathrm{g} \mathrm{BPA} / \mathrm{kg}$ bw/day by oral administration from the day after mating (gestation) through lactation (42 day duration).
- Adult BPA exposure of $F_{0}$ dams disrupts passive and active maternal care.

- These $F_{0}$ females spend decreased time licking and grooming pups and a trend to less ano-genital licking.

- These $F_{0}$ dams had reduced duration of time assuming an arched-back posture, which allows pups to suckle.

- $F_{0}$ adult BPA exposed dams did not demonstrate any differences in incidence of resting inside or outside of the nest.

- Lifelong BPA exposure of $F_{1}$ dams though resulted in them spending considerably less time outside of the nest.

- $F_{0}$ dams did not demonstrate any differences in nursing position

- $F_{1}$ dams spend less time assuming "arched" and "blanket" nursing positions. 
Table 1 | Continued

(Peromyscus californicus)

\begin{tabular}{llll}
\hline Publication(s) & $\begin{array}{l}\text { Animal model/human } \\
\text { cohort population }\end{array}$ & $\begin{array}{l}\text { EDC(s) tested or } \\
\text { correlation analysis } \\
\text { performed }\end{array}$ & $\begin{array}{l}\text { Dosing regimen/method to } \\
\text { measure BPA concentrations }\end{array}$ \\
\hline $\begin{array}{l}\text { Nakagami et al., } \\
2009\end{array}$ & $\begin{array}{l}\text { Cynomolgus monkeys } \\
\text { (Macaca fascicularis) }\end{array}$ & BPA & Male $\mathrm{F}_{1}$ infants exposed from \\
& & & $\begin{array}{l}\text { gestational day } 20 \text { through term to } \\
10 \mu \text { BPA/kg bw/day via osmotic } \\
\text { pump. }\end{array}$
\end{tabular}

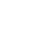

\section{Major findings}

- BPA-exposed $F_{1}$ male infant behavioral patterns in initiating maternal care became more reminiscent of female infants and subsequently these males were nursed less than control males.

- $F_{1}$ females were not examined in this study.

\section{- Perinatally BPA exposed $\mathrm{F}_{1}$} males show reduce territorial marking behavior when a control male was present in the testing arena.

- Perinatally BPA exposed $F_{1}$ females showed decrease exploratory and increased anxiety-like behaviors. dam through weaning at PND 30 , they weight in the diet.

$F_{1}$ males and females were placed on a control diet at weaning through adulthood.

\section{chxiety-like behaviors.}

\begin{tabular}{ll}
\hline Ward and Blum, 2012 & Native blacktail shiner \\
& fish (Cyprinella venusta) \\
& and introduced red shiner \\
& fish (C. venusta)
\end{tabular}

BPA fish (C. venusta)
Adult $F_{0}$ exposure for 14 days to BPA $1280 \mu \mathrm{g} / \mathrm{L}$ water (5.6 $\mu \mathrm{M})$.
- Adult BPA exposure of $F_{0}$ fish disrupted normal visual communication signals and abolished species-dependent sexually selected behavioral traits.

- Hybridization occured between these two otherwise behaviorally isolated species.

\begin{tabular}{|c|c|c|c|c|}
\hline Jasarevic et al., 2011 & $\begin{array}{l}\text { Deer mice } \\
\text { ( } P \text {. maniculatus bairdii) }\end{array}$ & BPA & $\begin{array}{l}\text { Two weeks prior to breeding of the } \mathrm{F}_{0} \\
\text { dam through weaning at PND } 21 \text {, they } \\
\text { were exposed to } 50 \mathrm{mg} \text { BPA/kg feed } \\
\text { weight in the diet. } \\
\mathrm{F}_{1} \text { males and females were placed on } \\
\text { a control diet at weaning through } \\
\text { adulthood. }\end{array}$ & $\begin{array}{l}\text { - } F_{1} \text { control and perinatally } \\
\text { BPA-exposed female } \\
\text { selectively rejected } F_{1} \text { males } \\
\text { prenatally exposed to BPA. }\end{array}$ \\
\hline Razzoli et al., 2005 & $\begin{array}{l}\text { Pair-bonded } \\
\text { monogamous Mongolian } \\
\text { gerbils (Meriones } \\
\text { unguiculatus) }\end{array}$ & BPA and EE2 & $\begin{array}{l}\text { Adult } F_{0} \text { females treated daily with } \\
\text { oral administration of BPA ( } 2 \text { or } \\
20 \mu \mathrm{g} / \mathrm{kg} \text { bw/day) or EE2 }(0.04 \mu \mathrm{g} / \mathrm{kg} \\
\text { bw/day) from day of pairing to day } 21 \\
\text { of cohabituation. }\end{array}$ & $\begin{array}{l}\text { - BPA and EE2 adult exposed } \\
F_{0} \text { females showed increase } \\
\text { investigation of their } F_{0} \\
\text { control male partner and } \\
\text { reduced exploration. }\end{array}$ \\
\hline $\begin{array}{l}\text { Wolstenholme et al., } \\
2013\end{array}$ & C57BI/6 mice & BPA & $\begin{array}{l}\text { Prenatal exposure (7-10 days prior to } \\
F_{0} \text { female being paired with a breeder } \\
\text { male and for a } 2 \text { week duration) and } \\
\text { ancestral exposure to } 5000 \mu \mathrm{g} / \mathrm{kg} \mathrm{fw} \\
\text { through the } F_{0} \text { maternal diet. }\end{array}$ & $\begin{array}{l}\text { - Prenatal and } \\
\text { transgenerational exposure to } \\
\text { BPA increased the amount of } \\
\text { time juvenile } \mathrm{F}_{1} \text { and } \mathrm{F}_{3} \text { male } \\
\text { and female mice spent } \\
\text { investigating a novel animal. } \\
\text { - } \mathrm{F}_{3} \text { females ancestrally } \\
\text { exposed to BPA persisted in } \\
\text { investigating novel females, } \\
\text { suggestive of impaired } \\
\text { dishabituation. }\end{array}$ \\
\hline
\end{tabular}


Table 1 | Continued

$\begin{array}{ll}\text { Publication(s) } & \begin{array}{l}\text { Animal model/human } \\ \text { cohort population }\end{array}\end{array}$

Porrini et al., 2005
EDC(s) tested or correlation analysis performed

\section{Dosing regimen/method to measure BPA concentrations}

Daily oral administration of $4000 \mu \mathrm{g}$ $\mathrm{BPA} / \mathrm{kg}$ bw/day to adult $\mathrm{F}_{0}$ dams from gestation through lactation (Mating through weaning of pups at PND 21) $\mathrm{F}_{1}$ females were not exposed to BPA after weaning.

Major findings

- Perinatal exposure of $F_{1}$ females exhibited reduced amount of time playing with males and engaging in social grooming.

- Findings are suggestive that developmental exposure to BPA may defeminize select social behaviors.

- $F_{1}$ BPA exposed males were not assessed in this study.

Dessi-Fulgheri et al., Sprague-Dawley rats BPA 2002

(1)

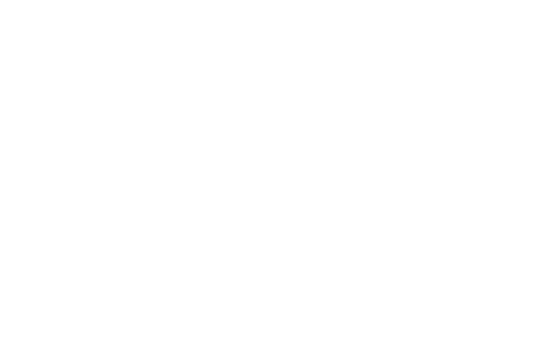

Wolstenholme et al., C57BI6J mice BPA
BPA Gestational exposure of $F_{1}$ offspring to $1250 \mu \mathrm{g} \mathrm{BPA} / \mathrm{kg}$ fw in the maternal diet.
Perinatal exposure of $F_{1}$ females to BPA either at $40 \mathrm{mg} / \mathrm{kg}$ bw/day via daily maternal $\left(F_{0}\right)$ oral dosing from conception to weaning or $400 \mathrm{mg} / \mathrm{kg}$ bw/day from gestational day 14 to postnatal day 6 .
- Perinatally BPA-exposed $F_{1}$ females, especially those exposed to the low dose, demonstrated a masculinized response in play behavior, as evident by their preference in playing with and engaging in socio-sexual exploration of other females.

- Perinatally BPA-exposed $\mathrm{F}_{1}$ males showed increase play behavior with females.

- Gestational exposure of both $F_{1}$ sexes resulted in increased play solicitations and approaches.
Gestational (gestational day 7 to PND 14) and lactational exposure of $F_{1}$ offspring to $50 \mu \mathrm{g} / \mathrm{kg}$ bw/day through daily maternal oral administration.

- Perinatally BPA-exposed $F_{1}$ males exhibited sexual behavioral deficits as adults.

- No disruptions were evident in the sexual behavioral of perinatally BPA exposed $F_{1}$ females.

- Neonatal BPA exposed $F_{1}$ females had later reductions in proceptive behaviors.

- Behaviors of neonatal BPA exposed $F_{1}$ males were not assessed. pups to $50 \mu \mathrm{g} / \mathrm{kg}$ bw/day or $20,000 \mu \mathrm{g} / \mathrm{kg}$ bw/day via daily subcutaneous injections.
- In ovo BPA exposure did not affect $F_{1}$ male copulatory behaviors.

- In ovo EB, DES, and genistein abolished copulatory behaviors of pubertal $F_{1}$ males.

- $F_{1}$ females were not assessed in this study. 
Table 1 | Continued

\begin{tabular}{ll} 
Publication(s) & $\begin{array}{l}\text { Animal model/human } \\
\text { cohort population }\end{array}$ \\
\hline Wibe et al., 2002; & $\begin{array}{l}\text { Threespine stickleback } \\
\text { (Gastrosteus aculeatus) } \\
\text { Kaplan et al., 2013 Mummichog } \\
\text { (Fundulus heteroclitus) }\end{array}$
\end{tabular}

Benzyl Butyl Phthalate (BBP)

\section{EDC(s) tested or correlation analysis performed}

Butyl Phthalate

(1)

(n)

\section{Dosing regimen/method to
measure BPA concentrations}

Adult $F_{0}$ exposure to $100 \mu \mathrm{g} / \mathrm{L}$ in the water $(0.32 \mu \mathrm{M})$ daily for 26 days (threespine stickleback) or 4 weeks (mummichog).

\section{Major findings}

- BPP-treated threespine stickleback fish aggregated in a single shoal that remained at the bottom of the aquarium.

- Mummichog exposed fish preferred to shoal with smaller size fish.

- Potential sex differences were not assessed in this study.

\begin{tabular}{|c|c|c|}
\hline Betz et al., 2013 & $\begin{array}{l}\text { Sprague-Dawley male } \\
\text { rats }\end{array}$ & BPP \\
\hline Lee et al., 2006 & Wistar-Imamichi rats & $\begin{array}{l}\text { Di-n-butyl phthalate } \\
\text { (DBP) } \\
\text { Diisononyl phthalate } \\
\text { (DINP) } \\
\text { Di-2-ethylhexyl adipate } \\
\text { (DEHA) }\end{array}$ \\
\hline
\end{tabular}

SOCIAL BEHAVIORS: HUMAN EPIDEMIOLOGICAL STUDIES
Perera et al., $2012 \quad 87$ boys and 111 girls spanning $3-5$ years of concentrations age $F_{0}$ males displayed aberrant

- $F_{0}$ females were not assessed in this study.

- DBP, DINP, and DEHA at several doses reduced copulatory behavior in perinatally exposed $F_{1}$ males.

- All doses of DBP, DINP, and DEHA decreased the lordosis quotient in perinatally exposed $F_{1}$ females.

- Linkage of prenatal BPA concentrations and increased emotionally reactive and
Five to six week old $\mathrm{F}_{0}$ males were provided 5000 and $10,000 \mathrm{mg} / \mathrm{L}$ in the drinking water $(0.16$ and $0.032 \mu \mathrm{M})$ until they were 20-21 weeks of age (15 week duration of exposure).

Perinatal exposure of $F_{1}$ offspring through the maternal diet from gestational day 15 to weaning (PND 21) to:

DBP- 20, 200, 2000, and

$10,000 \mathrm{mg} / \mathrm{kg}$ bw/day DINP- 40, 400, 4000, and $20,000 \mathrm{mg} / \mathrm{kg}$ bw/day DEHA- 480, 2400, and $12,000 \mathrm{mg} / \mathrm{kg}$ bw/dav

\section{Median maternal urinary}

concentrations at 34 weeks gestation: $1.8 \mu \mathrm{g} / \mathrm{L}(7.9 \mathrm{nM})$

Median child urinary concentrations at 3-4 years of age: $3.5 \mu \mathrm{g} / \mathrm{L}(15.3 \mathrm{nM})$
- Juvenile to adult BPP exposed social behaviors. aggressive behaviors in boys.

- Opposite effect in girls with increased exposure to BPA correlating with decreased anxiety and aggressive behaviors.

\begin{tabular}{llll}
\hline Evans et al., 2014 & $\begin{array}{l}\text { 77 boys and 76 girls } \\
\text { spanning 6-10 years of } \\
\text { age }\end{array}$ & $\begin{array}{l}\text { Maternal urinary BPA } \\
\text { concentrations }\end{array}$ & $\begin{array}{l}\text { Median maternal urinary BPA from 10 } \\
\text { to } 39 \text { weeks gestation with mean } \\
\text { gestational age at collection }=26.6 \\
\text { weeks: } 1.1 \mu \mathrm{g} / \mathrm{L}(4.8 \mathrm{nM})\end{array}$ \\
\hline Braun et al., 2009 & $\begin{array}{l}\text { 249 mothers and their } \\
\text { 2-year old children }\end{array}$ & $\begin{array}{l}\text { Maternal urinary BPA } \\
\text { concentrations }\end{array}$ & $\begin{array}{l}\text { Median maternal urinary } \\
\text { concentrations: } 1.3-1.8 \mu \mathrm{g} / \mathrm{L}\end{array}$ \\
& & $\begin{array}{l}(5.6-7.9 \mathrm{nM}), \text { as measured at } 16 \text { and } \\
26 \text { weeks gestation and at birth }\end{array}$
\end{tabular}

- Increased maternal urinary BPA concentrations linked with greater externalizing and aggressive behaviors in boys.

- Linkage of prenatal BPA concentrations (as determined by maternal urinary concentrations during pregnancy) and externalizing behaviors for girls but not boys.

\begin{tabular}{lll}
\hline Miodovnik et al., & 404 mothers and their & Maternal urinary BPA and \\
2011 & $7-9$ years of age children & 10 individual phthalate \\
& metabolite \\
& concentrations
\end{tabular}

Maternal urine was collected between 25 and 40 weeks gestation (mean $=$ 31.2 weeks). Median BPA concentration: $1.3 \mu \mathrm{g} / \mathrm{L}$ (5.6 nM) Median phthalate concentrations ranged from 1.6 to $430 \mathrm{ng} / \mathrm{ml}$
- Linkage with phthalate exposure and later childhood social impairments, including social cognition, communication, and awareness.

- No associations observed between BPA exposure and these behavioral disturbances. 
Table 1 | Continued

\begin{tabular}{|c|c|c|c|c|}
\hline Publication(s) & $\begin{array}{l}\text { Animal model/human } \\
\text { cohort population }\end{array}$ & $\begin{array}{l}\text { EDC(s) tested or } \\
\text { correlation analysis } \\
\text { performed }\end{array}$ & $\begin{array}{l}\text { Dosing regimen/method to } \\
\text { measure BPA concentrations }\end{array}$ & Major findings \\
\hline Lien et al., 2014 & $\begin{array}{l}122 \text { mothers and their } 8 \\
\text { year old children }\end{array}$ & $\begin{array}{l}\text { Maternal urinary } \\
\text { phthalate concentrations } \\
\text { (7 different forms) }\end{array}$ & $\begin{array}{l}\text { Maternal urine was collected in the } \\
\text { third trimester of gestation. } \\
\text { Geometric mean range of urinary } \\
\text { phthalate metabolite concentrations: } \\
26.8-109.1 \mu \mathrm{g} / \mathrm{g} \text { creatinine }\end{array}$ & $\begin{array}{l}\text { - Positive correlation with } \\
\text { perinatal exposure to } \\
\text { phthalates and delinquent } \\
\text { and aggressive behavioral } \\
\text { scores. }\end{array}$ \\
\hline Kobrosly et al., 2014 & $\begin{array}{l}153 \text { mothers and their } \\
6-10 \text { year old children }\end{array}$ & $\begin{array}{l}\text { Maternal urinary } \\
\text { phthalate concentrations } \\
\text { (monoisobutyl phthalate, } \\
\text { MiBP, and monobenzyl } \\
\text { phthalate, MBzP) }\end{array}$ & $\begin{array}{l}\text { Maternal urine was collected between } \\
10 \text { and } 39 \text { weeks gestation (mean }= \\
26.6 \text { weeks) } \\
\text { Median of } \mathrm{MiBP}=1.0 \mathrm{ng} / \mathrm{ml}(4.5 \mathrm{pM}) \\
\text { Median of } \mathrm{MBzP}=3.4 \mathrm{ng} / \mathrm{ml}(13.3 \\
\text { pM) }\end{array}$ & $\begin{array}{l}\text { - Boys of mothers with higher } \\
\text { urinary monoisobutyl } \\
\text { phthalate concentrations } \\
\text { were more likely to show } \\
\text { higher scores for inattention, } \\
\text { rule-breaking behavior, } \\
\text { aggression, and conduct } \\
\text { problems. } \\
\text { - Increased concentration of } \\
\text { monobenzyl phthalate was } \\
\text { correlated with conduct } \\
\text { problems in boys but reduced } \\
\text { anxiety scores in girls. }\end{array}$ \\
\hline
\end{tabular}

exposed for $1-4$ weeks to $11 \mathrm{ng} / \mathrm{L}$ water $(36.7 \mathrm{pM})$ of $17 \alpha$-ethinyl estradiol (EE2, estrogen in birth control pills) showed suppressed nest building activity, along with decreased courtship behaviors. These combined deficiencies thus likely effect successful fry rearing by exposed males. Future work is needed in monogamous and biparental rodent and other animal models to determine how developmental exposure to EDC affects paternal care and parenting providing by his partner.

\section{EVIDENCE THAT ENDOCRINE DISRUPTORS AFFECT SOCIAL BEHAVIORS}

Extensive data from retrospective human studies and animal models links perinatal exposure to EDCs and later social deficits (Table 1). The evidence in animal models will first be considered. Social behaviors to be considered include any that involve an interaction between difference members of the same species, such as various forms of communication, mate choice, pair bonding, social inquisitiveness and recognition, play behavior, social grooming, copulation, and aggression.

\section{ANIMAL MODELS}

Animal communication assumes various forms besides direct vocalizations. In California mice (Peromyscus californicus), males use territorial marking to communicate and protect their home range and mate from intruders. Males pericoceptionally through perinatally exposed (2 weeks prior to breeding of the dam through weaning at PND 30) to BPA $(50 \mathrm{mg} / \mathrm{kg}$ feed weight in the maternal diet) show reduction of this behavior when a control male is present in the testing arena (Williams et al., 2013). BPA exposure $(1280 \mu \mathrm{g} / \mathrm{L}$ water, $5.6 \mu \mathrm{M}$ for 14 days) of native blacktail shiner fish (Cyprinella venusta) and introduced red shiner fish (C. venusta) disrupts normal visual communication signals and abolishes the species-dependent sexually selected behavioral traits with the net potential for hybridization to occur between these two otherwise isolated species (Ward and Blum, 2012). Sprague-Dawley female rats prenatally exposed from gestational days 16 to 18 via daily intraperitoneal injection to the PCB mixture Aroclor (A) $1221(100 \mu \mathrm{g} / \mathrm{kg}, 1000 \mu \mathrm{g} / \mathrm{kg}$, and $10,000 \mu \mathrm{g} / \mathrm{kg}$ bw/day) have later vocalization deficits, as well as changes in mating patterns, movement and likelihood to mate (Steinberg et al., 2007).

Mate choice and pair-bonding formation are vulnerable to endocrine disruption. In mate choice trials, control and BPAexposed female deer mice ( $P$. maniculatus bairdii) selectively reject males developmentally exposed to BPA $(50 \mathrm{mg} / \mathrm{kg}$ feed weight through the maternal diet) (Jasarevic et al., 2011). Likewise, female $\mathrm{F}_{3}$ Sprague-Dawley rats prefer $\mathrm{F}_{3}$ males whose ancestors were not prenatally exposed to the anti-androgenic EDC, vinclozolin $(100 \mathrm{mg} / \mathrm{kg}$ bw/day from gestational days 8 to 14 via daily intraperitoneal injection) (Crews et al., 2007). Female sand gobies favor mating with control males, as opposed to those exposed for 7-24 days to EE2 (4 ng/L water, $13.3 \mathrm{nM}$ ) (Saaristo et al., 2009). Pair-bonded monogamous Mongolian gerbil (Meriones unguiculatus) females treated for a 3 week duration (from pairing to day 21 of cohabituation) with daily oral administration of either BPA ( 2 or $20 \mu \mathrm{g} / \mathrm{kg}$ bw/day) or EE2 $(0.04 \mu \mathrm{g} / \mathrm{kg}$ bw/day) exhibit heightened investigation of their partner and less exploration than untreated controls (Razzoli et al., 2005).

Introduction of new animals into the habitat results in social inquisitiveness and in time recognition of the new member with reduced bouts investigating this individual, i.e. habituation. Developmental and transgenerational exposure to BPA $\left(5000 \mu \mathrm{g} / \mathrm{kg}\right.$ feed weight through the $\mathrm{F}_{0}$ maternal diet 7-10 days prior to being paired with a breeder male and for 2 weeks thereafter) prolonged the duration of time juvenile $F_{1}$ and $F_{3}$ 
C57BL/6 mice, respectively, spend investigating a novel animal (Wolstenholme et al., 2013). Further, $\mathrm{F}_{3}$ females, whose ancestors were exposed to BPA, persisted in investigating novel females longer than controls, suggestive of impaired dishabituation.

Exposure to BPA may affect other socio-sexual behaviors, including play, social investigation, copulation, and aggression. Decrease amount of play with males and social grooming were evident in female Sprague-Dawley rats perinatally exposed to BPA $(4000 \mu \mathrm{g} / \mathrm{kg}$ bw/day to the dams via daily oral administration from mating through weaning at PND 21), which indicates that this chemical can defeminize select female social behaviors (Porrini et al., 2005). Sprague-Dawley rats exposed perinatally to BPA $(40 \mathrm{mg} / \mathrm{kg}$ bw/day from conception to weaning or $400 \mathrm{mg} / \mathrm{kg} /$ day from gestational day 14 to postnatal day 6 via daily maternal oral dosing) demonstrated masculinization of female social behaviors with such females selectively preferring to play with and engage in socio-sexual exploration of other females (Dessi-Fulgheri et al., 2002). Another study though with C57Bl6J mice suggests that gestational exposure to $1250 \mu \mathrm{g} \mathrm{BPA} / \mathrm{kg}$ feed weight increased play solicitations and approaches by both sexes (Wolstenholme et al., 2011b).

Sexual behaviors are also vulnerable to the early effects of BPA. Male LE rats, who received a "low dose" BPA $(50 \mu \mathrm{g} / \mathrm{kg}$ bw/day through maternal oral administration spanning gestation and lactation (gestational day 7 through PND 14), were sexually incompetent as adults, but no deficits in female sexual behavior were noted in this study (Jones et al., 2011). In contrast, another report found that neonatal exposure of inbred Wistar-derived female rats to BPA $(50 \mu \mathrm{g} / \mathrm{kg}$ bw/day or $20,000 \mu \mathrm{g} / \mathrm{kg}$ bw/day via daily subcutaneous injections to the pups) had later reductions in proceptive behaviors (Monje et al., 2009). While BPA exposure $(50,100$, and $200 \mu \mathrm{g}$ per egg) did overtly effect male Japanese quail (Coturnix japonica) copulatory behaviors, in ovo treatment with other estrogenic chemicals, including estradiol benzoate (10 or $25 \mu \mathrm{g}$ per egg), DES (700 ng per egg), and the soy phytoestrogen, genistein (1000 $\mu \mathrm{g}$ per egg), abolished this behavior in pubertal males (Panzica et al., 2005).

Current data demonstrate that phthalates can also affect varying social behaviors in rodents and fish. Benzyl butyl phthalate (BBP) exposure through the water $(100 \mu \mathrm{g} / \mathrm{L}, 0.32 \mu \mathrm{M})$ altered the shoaling behaviors (collection of fish for social purposes) in threespine stickleback (Gastrosteus aculeatus), who were treated each day for 26 days, and mummichog, a small killifish, (Fundulus heteroclitus), who were treated daily for 4 weeks (Wibe et al., 2002; Kaplan et al., 2013). BPP-treated threespine stickleback fish tended to aggregate in a single shoal that remained at the bottom of the test aquarium; whereas mummichog exposed fish preferred to shoal with smaller size fish. Male Sprague-Dawley rats exposed from adolescence to adulthood (5-6 weeks of age to 20-21 weeks of age) to BPP through the drinking water $(5000 \mu \mathrm{g} / \mathrm{L}$ and $10,000 \mu \mathrm{g} / \mathrm{L}$ or 0.016 and $0.032 \mu \mathrm{M}$, respectively) displayed aberrant social behaviors (Betz et al., 2013). Male and female Wistar-Imamichi rats developmentally exposed through the maternal diet from gestational day 15 through weaning (PND 21 ) to various phthalate chemicals (di-n-butyl phthalate, DBP20, 200, 2000, and $10,000 \mathrm{mg} / \mathrm{kg}$ bw/day; diisononyl phthalate, DINP- 40, 400, 4000, and 20,000 mg/kg bw/day; di-2-ethylhexyl adipate, DEHA- 480, 2400, and 12,000 mg/kg bw/day) exhibited sexual behavioral deficits (Lee et al., 2006). Copulatory behavior was diminished in male rats exposed to the varying doses of these chemicals. Similarly, the lordosis quotient was reduced in all treatment group females.

\section{HUMAN EPIDEMIOLOGICAL STUDIES}

Associations between early BPA exposure and social behavioral disruptions in children are generally based on urinary BPA concentrations in the mother or child (Table 1). An AfricanAmerican and Dominican women and their children population cohort that included 87 boys and 111 girls spanning 3-5 years of age showed higher exposure of BPA correlated with increased aggressive behaviors in boys but decreased aggression in girls (Perera et al., 2012). A more recent study with 153 six to ten year old children ( 77 boys and 76 girls) also demonstrated similar sex differences in vulnerability with increased maternal urinary BPA concentrations linked with greater externalizing and aggressive behaviors in boys (Evans et al., 2014). However, a study examining 249 mothers and their 2-year old children reported elevated prenatal BPA exposure associated with greater externalizing (aggression and hyperactivity) in girls but not boys (Braun et al., 2009).

Perinatal exposure to phthalates is also correlated with social behavioral disturbances. A study population of 404 mothers and their 7-9 years of age children pairs linked early contact to this chemical and later childhood social impairments, including social cognition, communication, and awareness (Miodovnik et al., 2011). This study however did not find any association between BPA exposure and effects on the examined social behaviors or sex-dependent differences. Examination of 122 mother-8 year old child pairs from Taiwan showed positive correlation of delinquent and aggressive behavioral scores and early exposure to different phthalate chemicals, as evidenced by maternal urinary concentrations (Lien et al., 2014). However, this study did not examine for potential sex-dependent differences. Another study with 153 mothers and their 6-10 year old children indicates that prenatal phthalate exposure is associated with later sex-dependent behavioral disturbances (Kobrosly et al., 2014). Boys of mothers with higher urinary monoisobutyl phthalate concentrations were more likely to show higher scores for inattention, rulebreaking behavior, aggression, and conduct problems; whereas increased concentration of monobenzyl phthalate was correlated with conduct problems in boys but reduced anxiety scores in girls.

\section{MECHANISMS BY WHICH ENDOCRINE DISRUPTORS MAY AFFECT PARENTAL AND SOCIAL BEHAVIORS DISRUPTION OF STEROID HORMONE PRODUCTION OR AT THE STEROID RECEPTOR LEVEL}

As detailed above, full elaboration of many social and parental behaviors is dependent on the organizational and activational effects of testosterone and estrogen (Phoenix et al., 1959; Arnold and Breedlove, 1985; Morris et al., 2004). Figure 1 illustrates the primary factors and enzymes required for normal testosterone and estrogen production. Both BPA and phthalates can affect steroidogenesis at several points in the pathway for males and females. Steroidogenic acute regulatory protein (StAR, STARD1) 


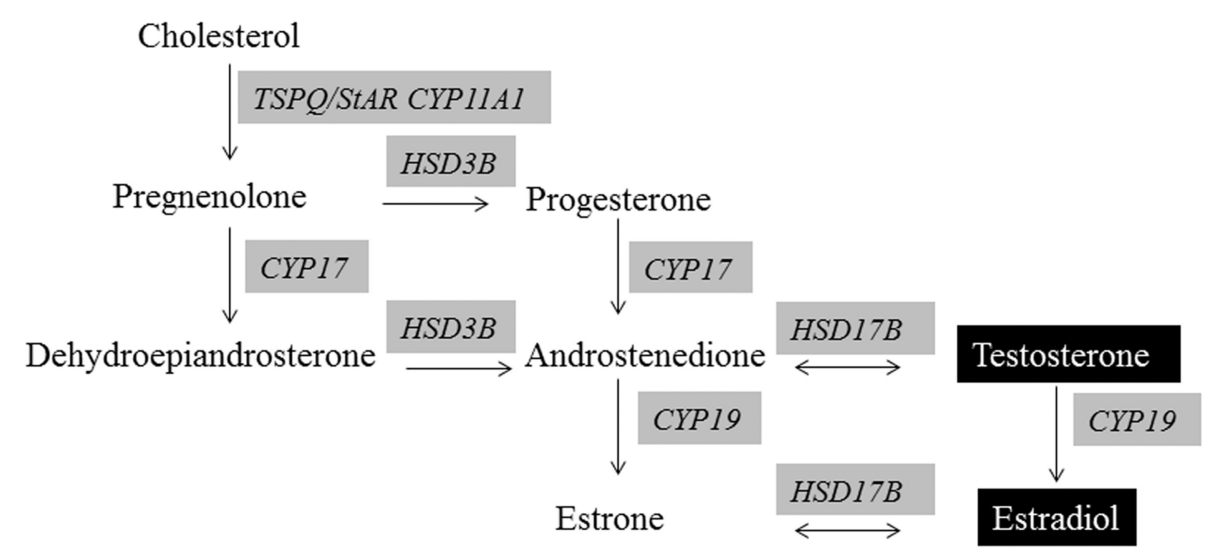

FIGURE 1 | Steroidogenesis of androgens and estrogens. Evidence exists that all of the shaded enzymes required in the synthesis of these hormones are altered by BPA and/or phthalate exposure.

is an essential mitochondrial protein for transporting cholesterol into the cell and is thus considered the rate-limiting step for steroid hormone production. BPA suppresses StAR mRNA expression in male and female gonads of rodents and fish (D'Cruz et al., 2012; Horstman et al., 2012; Liu et al., 2012; Peretz and Flaws, 2013; Savchuk et al., 2013). Expression of gonadal steroidogenic enzymes, including Cyp11, Hsd3b, Hsd17b, Cyp17, Cyp19 is also generally inhibited by BPA exposure (D'Cruz et al., 2012; Liu et al., 2012; Nanjappa et al., 2012; Peretz and Flaws, 2013; Savchuk et al., 2013).

Most animal model studies report BPA exposure decreases production of testosterone (T) and estrogen (E2) by male and female gonads (Akingbemi et al., 2004b; Peretz et al., 2011; D'Cruz et al., 2012; Nanjappa et al., 2012). However, a study with isolated porcine ovarian follicles suggests potential dosedependent effects with lower dose BPA concentrations $(0.1 \mathrm{mM})$ elevating E2; whereas large doses (1 and $10 \mathrm{~mm}$ ) suppressing E2 levels (Grasselli et al., 2010). In ovo BPA treatment (0.01 or $1.4 \mathrm{ppm}$ ) of Caiman latirostris eggs elevated E2 and lowered T concentrations and concomitantly reversed the normal temperature sex determination mechanisms with a predominance of females occurring in these groups (Stoker et al., 2008). In girls with precocious puberty, elevated urinary BPA concentrations were associated with elevated T, E2, and pregnenolone levels (Lee et al., 2014). Phthalate exposure is also associated with decreased StAR and steroidogenic enzyme expression and steroid hormone production (T and E2) by the male gonad (Akingbemi et al., 2001, 2004a; Svechnikov et al., 2008; Botelho et al., 2009; Chauvigne et al., 2011; Desdoits-Lethimonier et al., 2012; Saillenfait et al., 2013; Beverly et al., 2014), as well as circulating concentrations of T and E2 in men (Meeker et al., 2009). In contrast, one report identifying disrupted social interactions in phthalate-treated rats indicated that this chemical increased E2 concentrations (Betz et al., 2013).

BPA and phthalates may also disrupt normal organizational/activational steroidogenic effects by altering the expression of the cognate receptors, ESRs and AR, in the neural regions governing social and parental behaviors, namely the hypothalamus.
In this region, developmental exposure to BPA has been shown to alter the expression of ESR1 and ESR2 in rodent and ovine models, although the directionality is seemingly dependent upon sub-region, dose, time of assessment, and possibly species (Ramos et al., 2003; Ceccarelli et al., 2007; Monje et al., 2007; Mahoney and Padmanabhan, 2010; Cao et al., 2012, 2013, 2014; Patisaul et al., 2012; Kundakovic et al., 2013). Scant information exists on how phthalates may affect neural expression of ESRs and AR. The aforementioned rat phthalate study above also showed increased ESR1 expression in the amygdala of rats treated with $5 \mathrm{mg} / \mathrm{L}$ $(0.16 \mu \mathrm{M}) \mathrm{BBP}$ (Betz et al., 2013). Combined treatment of $4 \mathrm{wk}$ old rats with BPA $(285.4 \mathrm{mg} / \mathrm{kg})$ and DBP $(285.4 \mathrm{mg} / \mathrm{kg})$ in the feed increased AR expression in the brain (Zhang et al., 2013), which might render these animals more sensitive to endogenous and exogenous androgens.

\section{DISRUPTION OF THE HYPOTHALAMIC-PITUITARY-ADRENAL (HPA) AXIS}

BPA, phthalates, and other EDC exposure may disturb parental and social behaviors through disruptions in the classic stressassociated adrenocortical axis. One rat study showed that early BPA exposure (oral administration of $40 \mu \mathrm{g} / \mathrm{kg}$ bw/day to the dam throughout gestation and lactation) led to sex dependent effects on circulating corticosterone concentrations (elevated in BPA-exposed females) and neural (hippocampal expression) of $\mathrm{Gr}$ (lower expression in BPA-exposed males) (Poimenova et al., 2010). Further, BPA-treated female rats developmentally exposed to this same dosing regimen exhibited increased basal corticosterone and suppressed hypothalamic Gr expression (Panagiotidou et al., 2014).

Another study in rats where dams were subcutaneously injected with $2 \mu \mathrm{g} \mathrm{BPA} / \mathrm{kg}$ bw/day from gestational day 10 to lactational day 7 showed sex-dependent alterations in the adreno-cortical axis (Chen et al., 2014). BPA-exposed male rats had increased basal concentrations of serum corticosterone and adrenocorticotropin (ACTH) and corticotropin-releasing hormone $(\mathrm{Crh})$ mRNA expression, but these changes were not evident in exposed females. Following subsequent exposure to a mild 
stressor, corticosterone and ACTH concentrations increased further in BPA males; whereas, these hormones decreased in BPA females. In non-stressed animals, Gr mRNA was increased in the hippocampus and hypothalamic paraventricular nucleus of BPA females. In contrast, these transcripts decreased in BPA males. The collective results suggest that BPA exposure might affect the HPA axis in males and females but the specific effects are sex-dependent.

Phthalates also appear to disrupt the HPA axis. Oral exposure to DEHP (500 mg/kg bw/day for 4 days) increased concentrations of ACTH and corticosterone in treated male rats at 20 and 40 days of age; whereas no effects were observed in adult (60 days of age) males (Supornsilchai et al., 2007). Isolated adrenocortical cells from the 20 and 40 day old treated rats were more sensitized to the effects of ACTH, dibutyrl cAMP, and 22R-hydroxylase, as evidenced by increased production of corticosterone and ACTH treatment stimulated greater transport of endogenous cholesterol into the mitochondria.

\section{DISRUPTION OF NEUROPEPTIDE/PROTEIN HORMONES AND THEIR COGNATE RECEPTORS}

In the mouse and rat, central oxytocin receptors (OXTR) are obligatory for the expression of maternal behavior, and variation in OXTR levels in the medial preoptic area of the hypothalamus (MPOA) are functionally linked to differences in degree of maternal care (Champagne et al., 2006; Weaver, 2007). California mice fathers are known to exhibit increased oxytocin immunoreactivity compared to non-paternal males (Lambert et al., 2011). Increased signaling through the OXTR is correlated with high degree of maternal behavior, such as pup licking and grooming, while ESR1 is an important regulator of OXTR expression (Champagne et al., 2006). Prolactin, oxytocin, and vasopressin have been implicated in paternal care in California mice, monogamous prairie voles (Microtus ochrogaster), and humans (Gubernick and Nelson, 1989; Parker and Lee, 2001; Bales et al., 2004; Wynne-Edwards and Timonin, 2007; Gordon et al., 2010). Social behaviors are also dependent upon oxytocin, vasopressin, and protein binding to their cognate receptors in the brain (Carlson et al., 2006; Benarroch, 2013; Walker and McGlone, 2013; Wudarczyk et al., 2013; Babb et al., 2014; Lieberwirth and Wang, 2014).

Brains from 18.5 days post-coitus (dpc) mice exposed to BPA express less oxytocin, OXTR, and vasopressin than control males (Wolstenholme et al., 2011a, 2012). Reductions in brain expression for vasopressin persists in transgenerationally BPA exposed $\mathrm{F}_{4}$ males and females, and oxytocin is decreased in $\mathrm{F}_{4}$ males (Wolstenholme et al., 2012). Another study, however, suggests that in the paraventricular nucleus (PVN), oxytocinimmunnoreactive neurons increase in neonatally exposed BPA female Long Evans rats (Adewale et al., 2011), but non-pregnant, non-lactating females were examined. A recent study with juvenile prairie voles showed neonatal exposure to BPA increased AVP-immunoreactive neurons in the anterior PVN but decreased OT-immunoreactive neurons in this same region (Sullivan et al., 2014). In vivo and in vitro studies suggest that BPA increases PRL levels in male and female rats (Steinmetz et al., 1997; Goloubkova et al., 2000; Ramos et al., 2003; Delclos et al., 2014). Likewise, phthalate exposure is associated with elevated prolactin production in rats of both sexes and men (Lee et al., 2004; Li et al.,
2011). No previous study has assessed the effects of BPA or phthalate-exposure on PRL in parenting males and females.

\section{EPIMUTATIONS}

Epimutations are the most plausible mechanisms by which early exposure to BPA, phthalates, and other EDCs may lead to later neurobehavioral disturbances. Such changes may include alteration in DNA methylation, histone proteins, non-coding RNA, or chromatin arrangement. It is now apparent from a variety of animal model studies that BPA, phthlates, and other EDCs can lead to DNA methylation and corresponding gene expression changes in a variety of tissues, including the brain (Yaoi et al., 2008; Jang et al., 2012; Tang et al., 2012; Kundakovic et al., 2014; Zhao et al., 2014; Martinez-Arguelles and Papadopoulos, 2015).

Only two studies to date have shown BPA-induced DNA methylation changes in the brain. Developmental exposure to BPA alters the DNA methylation promoter state in many genes of the mouse forebrain (Yaoi et al., 2008). Persistent DNA methylation changes are evident in one of the promoters of $B d n f$ in the hippocampus and cord blood in female and male mice subjected to prenatal exposure to BPA with hypemethylation apparent in females but hypomethylation observed in males (Kundakovic et al., 2014). DNA methyl transferase (DNMT) and methyl CPG binding proteins (MECP) guide global DNA methylation changes.

BPA may simultaneously effect DNA methylation and histone protein modifications. For instance, exposure to BPA suppresses rat brain cortical expression of the ion transporter $(K c c 2)$ through both DNA methylation via MECP2 and histone protein (H3K9) binding to this gene (Yeo et al., 2013). Phthalates can also induce histone protein modifications in neuronal cells, as evidenced by phthalate-induced Sp3 suppression associated with deacetylation (via HDAC4) and ensuing polyubiquination in neuroblastoma cells (Guida et al., 2014).

The expression of Dnmt1, Dntm3a, Dnmt3b, and Mecp2 is altered in various brain regions, including basolateral amygdala, cortex, and hypothalamus, in BPA-treated rodent models (Kundakovic et al., 2013; Warita et al., 2013; Zhou et al., 2013). The histone protein modification enzyme (HDAC2) is upregulated in the hippocampus of adult males exposed to BPA (Zhang et al., 2014a). The histone methyltransferase enzyme (EZH2) and histone $\mathrm{H} 3$ trimethylation is upregulated in the mammary gland of mice exposed to BPA in utero and MCF-7 cells treated with this chemical (Doherty et al., 2010).

While no study has determined whether BPA exposure affects non-coding (nc) RNAs (including microRNAs, miRNAs) in the brain, there is evidence that this chemical can affect expression of these biomolecules in other cells, including MCF7 (Tilghman et al., 2012), ovarian (Veiga-Lopez et al., 2013), and placental cells (Avissar-Whiting et al., 2010). No study to date has assessed whether phthalate exposure affects ncRNAs in the brain or other regions.

\section{CONCLUSIONS}

Strong evidence exists that parental and social behaviors in a wide variety of species, including by translation humans, are vulnerable to perinatal exposure to EDCs, including BPA and phthalates. These effects are likely multifactorial in origin, but 
the net result is presumably that these chemicals disrupt normal organizational and activational programming of the brain. EDC-induced disruptions on neural programming may occur as a result of alterations in fetal or adult steroid hormone production, steroid receptor expression in the brain regions governing these traits, neuropeptide/protein hormones and their cognate receptors, and/or through epimutations. It remains to be determined though whether BPA, generally considered a "weak estrogen," results in similar mechanistic disruptions as phthalates with their predominantly anti-androgenic effects. Both chemicals can potentially disrupt all of the above pathways. Further, it is now apparent that both chemicals may lead to pleiotropic disturbances through steroidogenic and non-steroidogenic pathways (Leon-Olea et al., 2014).

EDC-induced parental and social behavioral deficits could affect the general livelihood, social well-being, ability to attract mate(s), reproduction, and likelihood of successfully rearing young. Thus, early exposure of animal and humans to these widely prevalent chemicals may lead to insidious behavioral effects. Moreover, there is ample evidence in animal models that EDCs (and humans in the case of DES) can induce transgenerational effects (Newbold et al., 2000, 2006; Klip et al., 2002; Titus-Ernstoff et al., 2006; Wolstenholme et al., 2012, 2013; Doyle et al., 2013; Manikkam et al., 2013; Schneider et al., 2013; Zhang et al., 2014b). Therefore, these chemicals might already be exhuming a toll on the social lives of unborn generations. While a call to action to legislate further these chemicals seems a reasonable course of action based on the existing data and precautionary principle, identifying the underpinning mechanisms leading to these behavioral disturbances might provide the incentive for policymakers to act. Long-term studies examining for linkages in parental deficiencies and transgenerational effects in human populations exposed to these EDCs may regrettably be needed before the production of such chemicals is minimized or outright banned.

\section{ACKNOWLEDGMENT}

The studies were supported by NIH Grant 5R21ES023150-02 (to C.S.R.).

\section{REFERENCES}

Adewale, H. B., Todd, K. L., Mickens, J. A., and Patisaul, H. B. (2011). The impact of neonatal bisphenol-a exposure on sexually dimorphic hypothalamic nuclei in the female rat. Neurotoxicology 32, 38-49. doi: 10.1016/j.neuro.2010.07.008

Akingbemi, B. T., Ge, R., Klinefelter, G. R., Zirkin, B. R., and Hardy, M. P. (2004a). Phthalate-induced Leydig cell hyperplasia is associated with multiple endocrine disturbances. Proc. Natl. Acad. Sci. U.S.A. 101, 775-780. doi: 10.1073/pnas. 0305977101

Akingbemi, B. T., Sottas, C. M., Koulova, A. I., Klinefelter, G. R., and Hardy, M. P. (2004b). Inhibition of testicular steroidogenesis by the xenoestrogen bisphenol A is associated with reduced pituitary luteinizing hormone secretion and decreased steroidogenic enzyme gene expression in rat Leydig cells. Endocrinology 145, 592-603. doi: 10.1210/en.2003-1174

Akingbemi, B. T., Youker, R. T., Sottas, C. M., Ge, R., Katz, E., Klinefelter, G. R., et al. (2001). Modulation of rat Leydig cell steroidogenic function by di(2-ethylhexyl)phthalate. Biol. Reprod. 65, 1252-1259. doi: 10.1095/biolreprod65.4.1252

Arnold, A. P., and Breedlove, S. M. (1985). Organizational and activational effects of sex steroids on brain and behavior: a reanalysis. Horm. Behav. 19, 469-498. doi: 10.1016/0018-506X(85)90042-X
Avissar-Whiting, M., Veiga, K. R., Uhl, K. M., Maccani, M. A., Gagne, L. A., Moen, E. L., et al. (2010). Bisphenol A exposure leads to specific microRNA alterations in placental cells. Reprod. Toxicol. 29, 401-406. doi: 10.1016/j.reprotox.2010.04.004

Babb, J. A., Carini, L. M., Spears, S. L., and Nephew, B. C. (2014). Transgenerational effects of social stress on social behavior, corticosterone, oxytocin, and prolactin in rats. Horm. Behav. 65, 386-393. doi: 10.1016/j.yhbeh.2014. 03.005

Bales, K. L., Kim, A. J., Lewis-Reese, A. D., and Sue Carter, C. (2004). Both oxytocin and vasopressin may influence alloparental behavior in male prairie voles. Horm. Behav. 45, 354-361. doi: 10.1016/j.yhbeh.2004.01.004

Benarroch, E. E. (2013). Oxytocin and vasopressin: social neuropeptides with complex neuromodulatory functions. Neurology 80, 1521-1528. doi: 10.1212/WNL.0b013e31828cfb15

Betz, A., Jayatilaka, S., Joshi, J., Ramanan, S., Debartolo, D., Pylypiw, H., et al. (2013). Chronic exposure to benzyl butyl phthalate (BBP) alters social interaction and fear conditioning in male adult rats: alterations in amygdalar MeCP2, ERK1/2 and ERalpha. Neuro Endocrinol. Lett. 34, 347-358.

Beverly, B. E., Lambright, C. S., Furr, J. R., Sampson, H., Wilson, V. S., McIntyre, B. S., et al. (2014). Simvastatin and dipentyl phthalate lower ex vivo testicular testosterone production and exhibit additive effects on testicular testosterone and gene expression via distinct mechanistic pathways in the fetal rat. Toxicol. Sci. 141, 524-537. doi: 10.1093/toxsci/kfu149

Botelho, G. G., Golin, M., Bufalo, A. C., Morais, R. N., Dalsenter, P. R., and Martino-Andrade, A. J. (2009). Reproductive effects of di(2ethylhexyl)phthalate in immature male rats and its relation to cholesterol, testosterone, and thyroxin levels. Arch. Environ. Contam. Toxicol. 57, 777-784. doi: 10.1007/s00244-009-9317-8

Boudalia, S., Berges, R., Chabanet, C., Folia, M., Decocq, L., Pasquis, B., et al. (2014). A multi-generational study on low-dose BPA exposure in Wistar rats: effects on maternal behavior, flavor intake and development. Neurotoxicol. Teratol. 41, 16-26. doi: 10.1016/j.ntt.2013.11.002

Braun, J. M., Yolton, K., Dietrich, K. N., Hornung, R., Ye, X., Calafat, A. M., et al. (2009). Prenatal bisphenol A exposure and early childhood behavior. Environ. Health Perspect. 117, 1945-1952. doi: 10.1289/ehp.0900979

Braun, K., and Champagne, F. A. (2014). Paternal influences on offspring development: behavioural and epigenetic pathways. J. Neuroendocrinol. 26, 697-706. doi: 10.1111/jne.12174

Bredy, T. W., Brown, R. E., and Meaney, M. J. (2007). Effect of resource availability on biparental care, and offspring neural and behavioral development in the California mouse (Peromyscus californicus). Eur. J. Neurosci. 25, 567-575. doi: 10.1111/j.1460-9568.2006.05266.x

Cao, J., Joyner, L., Mickens, J. A., Leyrer, S. M., and Patisaul, H. B. (2014). Sex-specific Esr2 mRNA expression in the rat hypothalamus and amygdala is altered by neonatal bisphenol A exposure. Reproduction 147, 537-554. doi: 10.1530/REP-13-0501

Cao, J., Mickens, J. A., McCaffrey, K. A., Leyrer, S. M., and Patisaul, H. B. (2012). Neonatal Bisphenol A exposure alters sexually dimorphic gene expression in the postnatal rat hypothalamus. Neurotoxicology 33, 23-36. doi: 10.1016/j.neuro.2011.11.002

Cao, J., Rebuli, M. E., Rogers, J., Todd, K. L., Leyrer, S. M., Ferguson, S. A., et al. (2013). Prenatal bisphenol A exposure alters sex-specific estrogen receptor expression in the neonatal rat hypothalamus and amygdala. Toxicol. Sci. 133, 157-173. doi: 10.1093/toxsci/kft035

Carlson, A. A., Russell, A. F., Young, A. J., Jordan, N. R., McNeilly, A. S., Parlow, A. F., et al. (2006). Elevated prolactin levels immediately precede decisions to babysit by male meerkat helpers. Horm. Behav. 50, 94-100. doi: 10.1016/j.yhbeh.2006.01.009

Ceccarelli, I., Della Seta, D., Fiorenzani, P., Farabollini, F., and Aloisi, A. M. (2007). Estrogenic chemicals at puberty change ERalpha in the hypothalamus of male and female rats. Neurotoxicol. Teratol. 29, 108-115. doi: 10.1016/j.ntt.2006.10.011

Champagne, F. A., Weaver, I. C., Diorio, J., Dymov, S., Szyf, M., and Meaney, M. J. (2006). Maternal care associated with methylation of the estrogen receptor-alphalb promoter and estrogen receptor-alpha expression in the medial preoptic area of female offspring. Endocrinology 147, 2909-2915. doi: 10.1210/en.2005-1119

Chauvigne, F., Plummer, S., Lesne, L., Cravedi, J. P., Dejucq-Rainsford, N., Fostier, A., et al. (2011). Mono-(2-ethylhexyl) phthalate directly alters the expression of 
Leydig cell genes and CYP17 lyase activity in cultured rat fetal testis. PLoS ONE 6:e27172. doi: 10.1371/journal.pone.0027172

Chen, F., Zhou, L., Bai, Y., Zhou, R., and Chen, L. (2014). Sex differences in the adult HPA axis and affective behaviors are altered by perinatal exposure to a low dose of bisphenol A. Brain Res. 1571, 12-24. doi: 10.1016/j.brainres.2014.05.010

Clutton-Brock, T. H. (1989). Mammalian mating systems. Proc. R. Soc. Lond. B Biol. Sci. 236, 339-372. doi: 10.1098/rspb.1989.0027

Crews, D., Gore, A. C., Hsu, T. S., Dangleben, N. L., Spinetta, M., Schallert, T., et al. (2007). Transgenerational epigenetic imprints on mate preference. Proc. Natl. Acad. Sci. U.S.A. 104, 5942-5946. doi: 10.1073/pnas.0610410104

Cummings, J. A., Nunez, A. A., and Clemens, L. G. (2005). A cross-fostering analysis of the effects of PCB 77 on the maternal behavior of rats. Physiol. Behav. 85, 83-91. doi: 10.1016/j.physbeh.2005.04.001

D'Cruz, S. C., Jubendradass, R., Jayakanthan, M., Rani, S. J., and Mathur, P. P. (2012). Bisphenol A impairs insulin signaling and glucose homeostasis and decreases steroidogenesis in rat testis: an in vivo and in silico study. Food Chem. Toxicol. 50, 1124-1133. doi: 10.1016/j.fct.2011.11.041

Delclos, K. B., Camacho, L., Lewis, S. M., Vanlandingham, M. M., Latendresse, J. R., Olson, G. R., et al. (2014). Toxicity evaluation of bisphenol A administered by gavage to Sprague Dawley rats from gestation day 6 through postnatal day 90. Toxicol. Sci. 139, 174-197. doi: 10.1093/toxsci/kfu022

Della Seta, D., Minder, I., Dessi-Fulgheri, F., and Farabollini, F. (2005). BisphenolA exposure during pregnancy and lactation affects maternal behavior in rats. Brain Res. Bull. 65, 255-260. doi: 10.1016/j.brainresbull.2004.11.017

Desdoits-Lethimonier, C., Albert, O., Le Bizec, B., Perdu, E., Zalko, D., Courant, F., et al. (2012). Human testis steroidogenesis is inhibited by phthalates. Hum. Reprod. 27, 1451-1459. doi: 10.1093/humrep/des069

Dessi-Fulgheri, F., Porrini, S., and Farabollini, F. (2002). Effects of perinatal exposure to bisphenol A on play behavior of female and male juvenile rats. Environ. Health Perspect. 110(Suppl. 3), 403-407. doi: 10.1289/ehp.02110s3403

Doherty, L. F., Bromer, J. G., Zhou, Y., Aldad, T. S., and Taylor, H. S. (2010). In utero exposure to diethylstilbestrol (DES) or bisphenol-A (BPA) increases EZH2 expression in the mammary gland: an epigenetic mechanism linking endocrine disruptors to breast cancer. Horm. Cancer 1, 146-155. doi: 10.1007/s12672-010$0015-9$

Doyle, T. J., Bowman, J. L., Windell, V. L., McLean, D. J., and Kim, K. H. (2013). Transgenerational effects of di-(2-ethylhexyl) phthalate on testicular germ cell associations and spermatogonial stem cells in mice. Biol. Reprod. 88, 112. doi: 10.1095/biolreprod.112.106104

Dulac, C., O'connell, L. A., and Wu, Z. (2014). Neural control of maternal and paternal behaviors. Science 345, 765-770. doi: 10.1126/science.1253291

Engell, M. D., Godwin, J., Young, L. J., and Vandenbergh, J. G. (2006). Perinatal exposure to endocrine disrupting compounds alters behavior and brain in the female pine vole. Neurotoxicol. Teratol. 28, 103-110. doi: 10.1016/j.ntt.2005.10.002

Environment Canada. (2008). Screening Assessment for the Challenge Phenol, 4,4' -(1-methylethylidene)bis-(Bisphenol A) Chemical Abstracts Service Registry Number 80-05-7. M.O.T.E.A.O. Health.

Evans, S. F., Kobrosly, R. W., Barrett, E. S., Thurston, S. W., Calafat, A. M., Weiss, B., et al. (2014). Prenatal Bisphenol A exposure and maternally reported behavior in boys and girls. Neurotoxicology 45, 91-99. doi: 10.1016/j.neuro.2014.10.003

Goloubkova, T., Ribeiro, M. F., Rodrigues, L. P., Cecconello, A. L., and Spritzer, P. M. (2000). Effects of xenoestrogen bisphenol A on uterine and pituitary weight, serum prolactin levels and immunoreactive prolactin cells in ovariectomized Wistar rats. Arch. Toxicol. 74, 92-98. doi: 10.1007/s002040050658

Gordon, I., Zagoory-Sharon, O., Leckman, J. F., and Feldman, R. (2010). Prolactin, Oxytocin, and the development of paternal behavior across the first six months of fatherhood. Horm. Behav. 58, 513-518. doi: 10.1016/j.yhbeh.2010. 04.007

Grandviewresearch. (2014). Global Bisphenol A (BPA) Market by Appliation (Appliances, Automotive, Consumer, Construction, Electrical \& Electronics) Expected to Reach USD 20.03 Billion by 2020. Available online at: http://www. digitaljournal.com/pr/2009287 (Accessed July 24, 2014).

Grasselli, F., Baratta, L., Baioni, L., Bussolati, S., Ramoni, R., Grolli, S., et al. (2010). Bisphenol A disrupts granulosa cell function. Domest. Anim. Endocrinol. 39, 34-39. doi: 10.1016/j.domaniend.2010.01.004

Gubernick, D. J., and Nelson, R. J. (1989). Prolactin and paternal behavior in the biparental California mouse, Peromyscus californicus. Horm. Behav. 23, 203-210. doi: 10.1016/0018-506X(89)90061-5
Guida, N., Laudati, G., Galgani, M., Santopaolo, M., Montuori, P., Triassi, M., et al. (2014). Histone deacetylase 4 promotes ubiquitin-dependent proteasomal degradation of Sp3 in SH-SY5Y cells treated with di(2-ethylhexyl)phthalate (DEHP), determining neuronal death. Toxicol. Appl. Pharmacol. 280, 190-198. doi: 10.1016/j.taap.2014.07.014

Hao, Y., Huang, W., Nielsen, D. A., and Kosten, T. A. (2011). Litter gender composition and sex affect maternal behavior and DNA methylation levels of the oprm1 gene in rat offspring. Front. Psychiatry 2:21. doi: 10.3389/fpsyt.2011. 00021

Horstman, K. A., Naciff, J. M., Overmann, G. J., Foertsch, L. M., Richardson, B. D., and Daston, G. P. (2012). Effects of transplacental 17-alpha-ethynyl estradiol or bisphenol A on the developmental profile of steroidogenic acute regulatory protein in the rat testis. Birth Defects Res. B Dev. Reprod. Toxicol. 95, 318-325. doi: $10.1002 / \mathrm{bdrb} .21020$

Howdeshell, K. L. (2002). A model of the development of the brain as a construct of the thyroid system. Environ. Health Perspect. 110(Suppl. 3), 337-348. doi: 10.1289/ehp.02110s3337

Jang, Y. J., Park, H. R., Kim, T. H., Yang, W. J., Lee, J. J., Choi, S. Y., et al. (2012). High dose bisphenol A impairs hippocampal neurogenesis in female mice across generations. Toxicology 296, 73-82. doi: 10.1016/j.tox.2012.03.007

Jasarevic, E., Sieli, P. T., Twellman, E. E., Welsh, T. H. Jr., Schachtman, T. R., Roberts, R. M., et al. (2011). Disruption of adult expression of sexually selected traits by developmental exposure to bisphenol A. Proc. Natl. Acad. Sci. U.S.A. 108 11715-11720. doi: 10.1073/pnas.1107958108

Jones, B. A., Shimell, J. J., and Watson, N. V. (2011). Pre- and postnatal bisphenol A treatment results in persistent deficits in the sexual behavior of male rats, but not female rats, in adulthood. Horm. Behav. 59, 246-251. doi: 10.1016/j.yhbeh.2010.12.006

Kaplan, L. A., Nabel, M., van Cleef-Toedt, K., Proffitt, A. R., and Pylypiw, H. M. Jr. (2013). Impact of benzyl butyl phthalate on shoaling behavior in Fundulus heteroclitus (mummichog) populations. Mar. Environ. Res. 86, 70-75. doi: 10.1016/j.marenvres.2013.02.014

Kendziorski, J. A., Kendig, E. L., Gear, R. B., and Belcher, S. M. (2012). Strain specific induction of pyometra and differences in immune responsiveness in mice exposed to 17alpha-ethinyl estradiol or the endocrine disrupting chemical bisphenol A. Reprod. Toxicol. 34, 22-30. doi: 10.1016/j.reprotox.2012.03.001

Klip, H., Verloop, J., van Gool, J. D., Koster, M. E., Burger, C. W., and van Leeuwen, F. E. (2002). Hypospadias in sons of women exposed to diethylstilbestrol in utero: a cohort study. Lancet 359, 1102-1107. doi: 10.1016/S01406736(02)08152-7

Kobrosly, R. W., Evans, S., Miodovnik, A., Barrett, E. S., Thurston, S. W., Calafat, A. M., et al. (2014). Prenatal phthalate exposures and neurobehavioral development scores in boys and girls at 6-10 years of age. Environ. Health Perspect. 122, 521-528. doi: 10.1289/ehp.1307063

Konkle, A. T., and McCarthy, M. M. (2011). Developmental time course of estradiol, testosterone, and dihydrotestosterone levels in discrete regions of male and female rat brain. Endocrinology 152, 223-235. doi: 10.1210/en. 2010-0607

Kundakovic, M., Gudsnuk, K., Franks, B., Madrid, J., Miller, R. L., Perera, F. P., et al. (2013). Sex-specific epigenetic disruption and behavioral changes following low-dose in utero bisphenol A exposure. Proc. Natl. Acad. Sci. U.S.A. 110, 9956-9961. doi: 10.1073/pnas.1214056110

Kundakovic, M., Gudsnuk, K., Herbstman, J. B., Tang, D., Perera, F. P., and Champagne, F. A. (2014). DNA methylation of BDNF as a biomarker of earlylife adversity. Proc. Natl. Acad. Sci. U.S.A. doi: 10.1073/pnas.1408355111. [Epub ahead of print].

Lambert, K. G., Franssen, C. L., Bardi, M., Hampton, J. E., Hainley, L., Karsner, S., et al. (2011). Characteristic neurobiological patterns differentiate paternal responsiveness in two Peromyscus species. Brain Behav. Evol. 77, 159-175. doi: $10.1159 / 000326054$

Latini, G., De Felice, C., Presta, G., Del Vecchio, A., Paris, I., Ruggieri, F., et al. (2003). In utero exposure to di-(2-ethylhexyl)phthalate and duration of human pregnancy. Environ. Health Perspect. 111, 1783-1785. doi: 10.1289/ ehp. 6202

Lee, H. C., Yamanouchi, K., and Nishihara, M. (2006). Effects of perinatal exposure to phthalate/adipate esters on hypothalamic gene expression and sexual behavior in rats. J. Reprod. Dev. 52, 343-352. doi: 10.1262/jrd.17096

Lee, K. Y., Shibutani, M., Takagi, H., Kato, N., Takigami, S., Uneyama, C., et al. (2004). Diverse developmental toxicity of di-n-butyl phthalate in both sexes 
of rat offspring after maternal exposure during the period from late gestation through lactation. Toxicology 203, 221-238. doi: 10.1016/j.tox.2004. 06.013

Lee, S. H., Kang, S. M., Choi, M. H., Lee, J., Park, M. J., Kim, S. H., et al. (2014). Changes in steroid metabolism among girls with precocious puberty may not be associated with urinary levels of bisphenol A. Reprod. Toxicol. 44, 1-6. doi: 10.1016/j.reprotox.2013.03.008

Leon-Olea, M., Martyniuk, C. J., Orlando, E. F., Ottinger, M. A., Rosenfeld, C. S., Wolstenholme, J. T., et al. (2014). Current concepts in neuroendocrine disruption. Gen. Comp. Endocrinol. 203, 158-173. doi: 10.1016/j.ygcen.2014. 02.005

Li, S., Dai, J., Zhang, L., Zhang, J., Zhang, Z., and Chen, B. (2011). An association of elevated serum prolactin with phthalate exposure in adult men. Biomed. Environ. Sci. 24, 31-39. doi: 10.3967/0895-3988

Lieberwirth, C., and Wang, Z. (2014). Social bonding: regulation by neuropeptides. Front. Neurosci. 8:171. doi: 10.3389/fnins.2014.00171

Lien, Y. J., Ku, H. Y., Su, P. H., Chen, S. J., Chen, H. Y., Liao, P. C., et al. (2014). Prenatal exposure to phthalate esters and behavioral syndromes in children at eight years of age: Taiwan maternal and infant cohort study. Environ. Health Perspect. 123, 95-100. doi: 10.1289/ehp.1307154

Liu, S., Qin, F., Wang, H., Wu, T., Zhang, Y., Zheng, Y., et al. (2012). Effects of 17alpha-ethinylestradiol and bisphenol A on steroidogenic messenger ribonucleic acid levels in the rare minnow gonads. Aquat. Toxicol. 122-123, 19-27. doi: 10.1016/j.aquatox.2012.05.010

Mahoney, M. M., and Padmanabhan, V. (2010). Developmental programming: impact of fetal exposure to endocrine-disrupting chemicals on gonadotropinreleasing hormone and estrogen receptor mRNA in sheep hypothalamus. Toxicol. Appl. Pharmacol. 247, 98-104. doi: 10.1016/j.taap.2010.05.017

Manikkam, M., Tracey, R., Guerrero-Bosagna, C., and Skinner, M. K. (2013) Plastics derived endocrine disruptors (BPA, DEHP and DBP) induce epigenetic transgenerational inheritance of obesity, reproductive disease and sperm epimutations. PLOS ONE 8:e55387. doi: 10.1371/journal.pone. 0055387

Martinez-Arguelles, D., and Papadopoulos, V. (2015). Identification of hot spots of DNA methylation in the adult male adrenal in response to in utero exposure to the ubiquitous endocrine disruptor plasticizer di-(2-ethylhexyl) phthalate. Endocrinology 156, 124-133. doi: 10.1210/en.2014-1436

McGhee, K. E., and Bell, A. M. (2014). Paternal care in a fish: epigenetics and fitness enhancing effects on offspring anxiety. Proc. Biol. Sci. 281, 20141146. doi: $10.1098 /$ rspb.2014.1146

Meeker, J. D., Calafat, A. M., and Hauser, R. (2009). Urinary metabolites of di(2-ethylhexyl) phthalate are associated with decreased steroid hormone levels in adult men. J. Androl. 30, 287-297. doi: 10.2164/jandrol.108. 006403

Miodovnik, A., Engel, S. M., Zhu, C., Ye, X., Soorya, L. V., Silva, M. J., et al. (2011) Endocrine disruptors and childhood social impairment. Neurotoxicology 32, 261-267. doi: 10.1016/j.neuro.2010.12.009

Monje, L., Varayoud, J., Luque, E. H., and Ramos, J. G. (2007). Neonatal exposure to bisphenol A modifies the abundance of estrogen receptor alpha transcripts with alternative $5^{\prime}$-untranslated regions in the female rat preoptic area. J. Endocrinol. 194, 201-212. doi: 10.1677/JOE-07-0014

Monje, L., Varayoud, J., Munoz-De-Toro, M., Luque, E. H., and Ramos, J. G. (2009). Neonatal exposure to bisphenol A alters estrogen-dependent mechanisms governing sexual behavior in the adult female rat. Reprod. Toxicol. 28, 435-442. doi: 10.1016/j.reprotox.2009.06.012

Morris, J. A., Jordan, C. L., and Breedlove, S. M. (2004). Sexual differentiation of the vertebrate nervous system. Nat. Neurosci. 7, 1034-1039. doi: 10.1038/ nn1325

Nakagami, A., Negishi, T., Kawasaki, K., Imai, N., Nishida, Y., Ihara, T., et al. (2009). Alterations in male infant behaviors towards its mother by prenatal exposure to bisphenol A in cynomolgus monkeys (Macaca fascicularis) during early suckling period. Psychoneuroendocrinology 34, 1189-1197. doi: 10.1016/j.psyneuen.2009.03.005

Nanjappa, M. K., Simon, L., and Akingbemi, B. T. (2012). The industrial chemical bisphenol A (BPA) interferes with proliferative activity and development of steroidogenic capacity in rat Leydig cells. Biol. Reprod. 86:135. doi: 10.1095/ biolreprod.111.095349

Newbold, R. R., Hanson, R. B., Jefferson, W. N., Bullock, B. C., Haseman, J., and McLachlan, J. A. (2000). Proliferative lesions and reproductive tract tumors in male descendants of mice exposed developmentally to diethylstilbestrol. Carcinogenesis 21, 1355-1363. doi: 10.1093/carcin/21.7.1355

Newbold, R. R., Padilla-Banks, E., and Jefferson, W. N. (2006). Adverse effects of the model environmental estrogen diethylstilbestrol are transmitted to subsequent generations. Endocrinology 147, S11-S17. doi: 10.1210/en.2005-1164

Palanza, P., Howdeshell, K. L., Parmigiani, S., and Vom Saal, F. S. (2002). Exposure to a low dose of bisphenol A during fetal life or in adulthood alters maternal behavior in mice. Environ. Health Perspect. 110, 415-422. doi: 10.1289/ehp.02110s3415

Panagiotidou, E., Zerva, S., Mitsiou, D. J., Alexis, M. N., and Kitraki, E. (2014). Perinatal exposure to low-dose bisphenol A affects the neuroendocrine stress response in rats. J. Endocrinol. 220, 207-218. doi: 10.1530/JOE-13-0416

Panzica, G., Mura, E., Pessatti, M., and Viglietti-Panzica, C. (2005). Early embryonic administration of xenoestrogens alters vasotocin system and male sexual behavior of the Japanese quail. Domest. Anim. Endocrinol. 29, 436-445. doi: 10.1016/j.domaniend.2005.02.010

Parker, K. J., and Lee, T. M. (2001). Central vasopressin administration regulates the onset of facultative paternal behavior in microtus pennsylvanicus (meadow voles). Horm. Behav. 39, 285-294. doi: 10.1006/hbeh.2001.1655

Patisaul, H. B., Sullivan, A. W., Radford, M. E., Walker, D. M., Adewale, H. B., Winnik, B., et al. (2012). Anxiogenic effects of developmental bisphenol A exposure are associated with gene expression changes in the juvenile rat amygdala and mitigated by soy. PLOS ONE 7:e43890. doi: 10.1371/journal.pone. 0043890

Perera, F., Vishnevetsky, J., Herbstman, J. B., Calafat, A. M., Xiong, W., Rauh, V., et al. (2012). Prenatal bisphenol A exposure and child behavior in an inner-city cohort. Environ. Health Perspect. 120, 1190-1194. doi: 10.1289/ehp. 1104492

Peretz, J., and Flaws, J. A. (2013). Bisphenol A down-regulates rate-limiting Cyp1la1 to acutely inhibit steroidogenesis in cultured mouse antral follicles. Toxicol. Appl. Pharmacol. 271, 249-256. doi: 10.1016/j.taap.2013.04.028

Peretz, J., Gupta, R. K., Singh, J., Hernandez-Ochoa, I., and Flaws, J. A. (2011). Bisphenol A impairs follicle growth, inhibits steroidogenesis, and downregulates rate-limiting enzymes in the estradiol biosynthesis pathway. Toxicol. Sci. 119, 209-217. doi: 10.1093/toxsci/kfq319

Phoenix, C. H., Goy, R. W., Gerall, A. A., and Young, W. C. (1959). Organizing action of prenatally administered testosterone propionate on the tissues mediating mating behavior in the female guinea pig. Endocrinology 65, 369-382. doi: 10.1210/endo-65-3-369

Poimenova, A., Markaki, E., Rahiotis, C., and Kitraki, E. (2010). Corticosterone-regulated actions in the rat brain are affected by perinatal exposure to low dose of bisphenol A. Neuroscience 167, 741-749. doi: 10.1016/j.neuroscience.2010.02.051

Porrini, S., Belloni, V., Della Seta, D., Farabollini, F., Giannelli, G., and DessiFulgheri, F. (2005). Early exposure to a low dose of bisphenol A affects socio-sexual behavior of juvenile female rats. Brain Res. Bull. 65, 261-266. doi: 10.1016/j.brainresbull.2004.11.014

Ramos, J. G., Varayoud, J., Kass, L., Rodriguez, H., Costabel, L., Munoz-DeToro, M., et al. (2003). Bisphenol a induces both transient and permanent histofunctional alterations of the hypothalamic-pituitary-gonadal axis in prenatally exposed male rats. Endocrinology 144, 3206-3215. doi: 10.1210/en. 2002-0198

Razzoli, M., Valsecchi, P., and Palanza, P. (2005). Chronic exposure to low doses bisphenol A interferes with pair-bonding and exploration in female Mongolian gerbils. Brain Res. Bull. 65, 249-254. doi: 10.1016/j.brainresbull.2004. 11.013

Rice, D., and Barone, S. Jr. (2000). Critical periods of vulnerability for the developing nervous system: evidence from humans and animal models. Environ. Health Perspect. 108(Suppl. 3), 511-533. doi: 10.1289/ehp.00108s3511

Rilling, J. K., and Young, L. J. (2014). The biology of mammalian parenting and its effect on offspring social development. Science 345, 771-776. doi: $10.1126 /$ science. 1252723

Rosenfeld, C. S. (2014). "Animal models of transgenerational epigenetic effects," in Transgenerational Epigenetics, ed. T. Tollefsbol (London: Elsevier Publications), 123-145.

Saaristo, M., Craft, J. A., Lehtonen, K. K., and Lindstrom, K. (2009). Sand goby (Pomatoschistus minutus) males exposed to an endocrine disrupting chemical fail in nest and mate competition. Horm. Behav. 56, 315-321. doi: 10.1016/j.yhbeh.2009.06.010 
Saaristo, M., Craft, J. A., Lehtonen, K. K., and Lindstrom, K. (2010). An endocrine disrupting chemical changes courtship and parental care in the sand goby. Aquat. Toxicol. 97, 285-292. doi: 10.1016/j.aquatox.2009.12.015

Saillenfait, A. M., Sabate, J. P., Robert, A., Rouiller-Fabre, V., Roudot, A. C., Moison, D., et al. (2013). Dose-dependent alterations in gene expression and testosterone production in fetal rat testis after exposure to di-n-hexyl phthalate. J. Appl. Toxicol. 33, 1027-1035. doi: 10.1002/jat.2896

Savchuk, I., Soder, O., and Svechnikov, K. (2013). Mouse leydig cells with different androgen production potential are resistant to estrogenic stimuli but responsive to bisphenol a which attenuates testosterone metabolism. PLoS ONE 8:e71722. doi: 10.1371/journal.pone.0071722

Schneider, S., Marxfeld, H., Groters, S., Buesen, R., and van Ravenzwaay, B. (2013). Vinclozolin-no transgenerational inheritance of anti-androgenic effects after maternal exposure during organogenesis via the intraperitoneal route. Reprod. Toxicol. 37, 6-14. doi: 10.1016/j.reprotox.2012.12.003

Spearow, J. L., Doemeny, P., Sera, R., Leffler, R., and Barkley, M. (1999). Genetic variation in susceptibility to endocrine disruption by estrogen in mice. Science 285, 1259-1261. doi: 10.1126/science.285.5431.1259

Spearow, J. L., O’Henley, P., Doemeny, P., Sera, R., Leffler, R., Sofos, T., et al. (2001). Genetic variation in physiological sensitivity to estrogen in mice. APMIS 109 , 356-364. doi: 10.1034/j.1600-0463.2001.090504.x

Steinberg, R. M., Juenger, T. E., and Gore, A. C. (2007). The effects of prenatal PCBs on adult female paced mating reproductive behaviors in rats. Horm. Behav. 51, 364-372. doi: 10.1016/j.yhbeh.2006.12.004

Steinmetz, R., Brown, N. G., Allen, D. L., Bigsby, R. M., and Ben-Jonathan, N. (1997). The environmental estrogen bisphenol A stimulates prolactin release in vitro and in vivo. Endocrinology 138, 1780-1786.

Stoker, C., Beldomenico, P. M., Bosquiazzo, V. L., Zayas, M. A., Rey, F., Rodriguez, H., et al. (2008). Developmental exposure to endocrine disruptor chemicals alters follicular dynamics and steroid levels in Caiman latirostris. Gen. Comp. Endocrinol. 156, 603-612. doi: 10.1016/j.ygcen.2008.02.011

Sullivan, A. W., Beach, E. C., Stetzik, L. A., Perry, A., D’Addezio, A. S., Cushing, B. S., et al. (2014). A novel model for neuroendocrine toxicology: neurobehavioral effects of BPA exposure in a prosocial species, the prairie vole (Microtus ochrogaster). Endocrinology 155, 3867-3881. doi: 10.1210/en. 2014-1379

Supornsilchai, V., Soder, O., and Svechnikov, K. (2007). Stimulation of the pituitary-adrenal axis and of adrenocortical steroidogenesis ex vivo by administration of di-2-ethylhexyl phthalate to prepubertal male rats. J. Endocrinol. 192, 33-39. doi: 10.1677/JOE-06-0004

Svechnikov, K., Svechnikova, I., and Soder, O. (2008). Inhibitory effects of monoethylhexyl phthalate on steroidogenesis in immature and adult rat Leydig cells in vitro. Reprod. Toxicol. 25, 485-490. doi: 10.1016/j.reprotox.2008.05.057

Tang, W. Y., Morey, L. M., Cheung, Y. Y., Birch, L., Prins, G. S., and Ho, S. M. (2012). Neonatal exposure to estradiol/bisphenol A alters promoter methylation and expression of Nsbpl and Hpcall genes and transcriptional programs of Dnmt3a/b and Mbd2/4 in the rat prostate gland throughout life. Endocrinology 153, 42-55. doi: 10.1210/en.2011-1308

Tilghman, S. L., Bratton, M. R., Segar, H. C., Martin, E. C., Rhodes, L. V., Li, M., et al. (2012). Endocrine disruptor regulation of microRNA expression in breast carcinoma cells. PLoS ONE 7:e32754. doi: 10.1371/journal.pone.0032754

Titus-Ernstoff, L., Troisi, R., Hatch, E. E., Wise, L. A., Palmer, J., Hyer, M., et al. (2006). Menstrual and reproductive characteristics of women whose mothers were exposed in utero to diethylstilbestrol (DES). Int. J. Epidemiol. 35, 862-868. doi: 10.1093/ije/dyl106

Vandenberg, L. N., Ehrlich, S., Belcher, S. M., Ben-Jonathan, N., Dolinoy, D. C., Hugo, E. S., et al. (2013). Low dose effects of bisphenol A: an integrated review of in vitro, laboratory animal and epidemiology studies. Endocr. Disruption 1, E1-E20. doi: 10.4161/endo.26490

Veiga-Lopez, A., Luense, L. J., Christenson, L. K., and Padmanabhan, V. (2013). Developmental programming: gestational bisphenol-A treatment alters trajectory of fetal ovarian gene expression. Endocrinology 154, 1873-1884. doi: 10.1210/en.2012-2129

Walker, S. C., and McGlone, F. P. (2013). The social brain: neurobiological basis of affiliative behaviours and psychological well-being. Neuropeptides 47, 379-393. doi: 10.1016/j.npep.2013.10.008

Ward, J. L., and Blum, M. J. (2012). Exposure to an environmental estrogen breaks down sexual isolation between native and invasive species. Evol. Appl. 5, 901-912. doi: 10.1111/j.1752-4571.2012.00283.x
Warita, K., Mitsuhashi, T., Ohta, K., Suzuki, S., Hoshi, N., Miki, T., et al. (2013). Gene expression of epigenetic regulatory factors related to primary silencing mechanism is less susceptible to lower doses of bisphenol A in embryonic hypothalamic cells. J. Toxicol. Sci. 38, 285-289. doi: 10.2131/jts. 38.285

Watson, J., and Adkins-Regan, E. (1989). Activation of sexual behavior by implantation of testosterone propionate and estradiol benzoate into the preoptic area of the male Japanese quail (Coturnix japonica). Horm. Behav. 23, 251-268. doi: 10.1016/0018-506X(89)90065-2

Weaver, I. C. (2007). Epigenetic programming by maternal behavior and pharmacological intervention. Nature versus nurture: let's call the whole thing off. Epigenetics 2, 22-28. doi: 10.4161/epi.2.1.3881

Weaver, I. C., Meaney, M. J., and Szyf, M. (2006). Maternal care effects on the hippocampal transcriptome and anxiety-mediated behaviors in the offspring that are reversible in adulthood. Proc. Natl. Acad. Sci. U.S.A. 103, 3480-3485. doi: 10.1073/pnas.0507526103

Wibe, A. E., Billing, A., Rosenqvist, G., and Jenssen, B. M. (2002). Butyl benzyl phthalate affects shoaling behavior and bottom-dwelling behavior in threespine stickleback. Environ. Res. 89, 180-187. doi: 10.1006/enrs.2002.4360

Williams, S. A., Jasarevic, E., Vandas, G. M., Warzak, D. A., Geary, D. C., Ellersieck, M. R., et al. (2013). Effects of developmental bisphenol A exposure on reproductive-related behaviors in California mice (Peromyscus californicus): a monogamous animal model. PLoS ONE 8:e55698. doi: 10.1371/journal.pone.0055698

Wolstenholme, J. T., Edwards, M., Shetty, S. R., Gatewood, J. D., Taylor, J. A. Rissman, E. F., et al. (2012). Gestational exposure to bisphenol a produces transgenerational changes in behaviors and gene expression. Endocrinology 153, 3828-3838. doi: 10.1210/en.2012-1195

Wolstenholme, J. T., Goldsby, J. A., and Rissman, E. F. (2013). Transgenerational effects of prenatal bisphenol A on social recognition. Horm. Behav. 64, 833-839. doi: 10.1016/j.yhbeh.2013.09.007

Wolstenholme, J. T., Rissman, E. F., and Connelly, J. J. (2011a). The role of bisphenol A in shaping the brain, epigenome and behavior. Horm. Behav. 59, 296-305. doi: 10.1016/j.yhbeh.2010.10.001

Wolstenholme, J. T., Taylor, J. A., Shetty, S. R., Edwards, M., Connelly, J. J., and Rissman, E. F. (2011b). Gestational exposure to low dose bisphenol A alters social behavior in juvenile mice. PLoS ONE 6:e25448. doi: 10.1371/journal.pone.0025448

Wudarczyk, O. A., Earp, B. D., Guastella, A., and Savulescu, J. (2013). Could intranasal oxytocin be used to enhance relationships? Research imperatives, clinical policy, and ethical considerations. Curr. Opin. Psychiatry 26, 474-484 doi: 10.1097/YCO.0b013e3283642e10

Wynne-Edwards, K. E., and Timonin, M. E. (2007). Paternal care in rodents: weakening support for hormonal regulation of the transition to behavioral fatherhood in rodent animal models of biparental care. Horm. Behav. 52, 114-121. doi: 10.1016/j.yhbeh.2007.03.018

Yaoi, T., Itoh, K., Nakamura, K., Ogi, H., Fujiwara, Y., and Fushiki, S. (2008) Genome-wide analysis of epigenomic alterations in fetal mouse forebrain after exposure to low doses of bisphenol A. Biochem. Biophys. Res. Commun. 376, 563-567. doi: 10.1016/j.bbrc.2008.09.028

Yeo, M., Berglund, K., Hanna, M., Guo, J. U., Kittur, J., Torres, M. D., et al. (2013). Bisphenol A delays the perinatal chloride shift in cortical neurons by epigenetic effects on the Kcc2 promoter. Proc. Natl. Acad. Sci. U.S.A. 110, 4315-4320. doi: $10.1073 /$ pnas. 1300959110

Zhang, Q., Xu, X., Li, T., Lu, Y., Ruan, Q., Lu, Y., et al. (2014a). Exposure to bisphenol-A affects fear memory and histone acetylation of the hippocampus in adult mice. Horm. Behav. 65, 106-113. doi: 10.1016/j.yhbeh.2013.12.004

Zhang, W. Z., Yong, L., Jia, X. D., Li, N., and Fan, Y. X. (2013). Combined subchronic toxicity of bisphenol A and dibutyl phthalate on male rats. Biomed Environ. Sci. 26, 63-69. doi: 10.3967/0895-3988.2013.01.008

Zhang, X. F., Zhang, T., Han, Z., Liu, J. C., Liu, Y. P., Ma, J. Y., et al. (2014b) Transgenerational inheritance of ovarian development deficiency induced by maternal diethylhexyl phthalate exposure. Reprod. Fertil. Dev. doi: 10.1071/ RD14113. [Epub ahead of print].

Zhao, Y., Shi, H. J., Xie, C. M., Chen, J., Laue, H., and Zhang, Y. H. (2014). Prenatal phthalate exposure, infant growth, and global DNA methylation of human placenta. Environ. Mol. Mutagen. doi: 10.1002/em.21916. [Epub ahead of print].

Zhou, R., Chen, F., Chang, F., Bai, Y., and Chen, L. (2013). Persistent overexpression of DNA methyltransferase 1 attenuating GABAergic inhibition 
in basolateral amygdala accounts for anxiety in rat offspring exposed perinatally to low-dose bisphenol A. J. Psychiatr. Res. 47, 1535-1544. doi: 10.1016/j.jpsychires.2013.05.013

Conflict of Interest Statement: The author declares that the research was conducted in the absence of any commercial or financial relationships that could be construed as a potential conflict of interest.

Received: 21 November 2014; accepted: 09 February 2015; published online: 03 March 2015.
Citation: Rosenfeld CS (2015) Bisphenol A and phthalate endocrine disruption of parental and social behaviors. Front. Neurosci. 9:57. doi: 10.3389/fnins.2015.00057 This article was submitted to Neuroendocrine Science, a section of the journal Frontiers in Neuroscience.

Copyright () 2015 Rosenfeld. This is an open-access article distributed under the terms of the Creative Commons Attribution License (CC BY). The use, distribution or reproduction in other forums is permitted, provided the original author(s) or licensor are credited and that the original publication in this journal is cited, in accordance with accepted academic practice. No use, distribution or reproduction is permitted which does not comply with these terms. 